\title{
Film Anlatısında Kahramanın Değişen Özne Konumu: Başkalarının Hayatı Filmi Örneği
}

\author{
Burak Medin (Dr. Öğr. Üyesi) \\ Erciyes Üniversitesi İletişim Fakültesi \\ burakmedin@erciyes.edu.tr \\ Orcid: 0000-0001-8012-035X
}

Başvuru Tarihi: 01.08.2018

Yayına Kabul Tarihi: 17.10.2018

Yayınlanma Tarihi: 31.01.2019

Öz

Geçmişten günümüze sinemasal anlatılar, sundukları öykünün taşıyıcısı olan kahramanlar/özneler aracılığıyla geniş kitlelere ulaşır. İzler kitlenin ilgisi ve dikkati, inşa edilen kahraman konumundaki özneler aracılığıyla çekilir. İzleyici, anlatıda önemli bir eyleyen olan kahramandan hareketle özdeşlik ilişkisini başlatır. Klasik, çağdaş ya da postmodern anlatılarda kahramanın inşasıyla ilgili durum farklılık gösterse de yine de anlatı içinde aranan en önemli eyleyen, öznedir. Bu eksende kahramanların özne konumları açısından irdelenmesi sinemasal dünyayı/yolculuğu anlamlandırabilmek adına önem taşır. Bu bağlamda bu çalışmada özne konumundaki kahramana ve öznenin izlencesini kuran, başlatan ve ileriye doğru devindiren yitik/ arzu nesnesine odaklanıldı. Özneyi özdeşlik kurulabilecek ideal egoya/doğruluk öznesine dönüştüren unsurlar da bu çalışmada ele alınan bir diğer önemli başlıktır. Değișen özne konumunu anlayabilmede önemli potansiyeller taşıdığı varsayılan Başkalarının Hayatı (The Lives of Others) filmi bu çalışmanın araștırma nesnesidir. Araştırma nesnesi konumunda olan bu film anlatısı özne konumu açısından A. J. Greimas'ın "Eyleyensel Örnekçe" ve "Dörtlü Şema" kuramı bağlamında çözümlendi. Benlik; kahramanın izlencesini, değişimini ve dönüşümünü anlamak adına önem taşıyan bir başka unsurdur. Bu bağlamda göstergebilimsel yaklaşımın yanı sıra E. Goffman'ın "Dramaturjik İlkeleri”nden ve bu ilkelerden hareketle ortaya koyduğu mikro-sosyolojik kavramlarından da çözümleme sırasında yararlanıldı.

Anahtar Kelimeler: Sinema, Film Eleştiri, Eyleyensel Örnekçe, Dörtlü Şema, Özne, Benlik. 


\title{
Hero's Changing Subject Position in Film Narrative: Case Study of the Lives of Others
}

\author{
Burak Medin (Asst. Prof. Dr.) \\ Erciyes University Faculty of Communication \\ burakmedin@erciyes.edu.tr \\ Orcid: 0000-0001-8012-035X
}

Date Received: 01.08.2018

Date Accepted: 17.10.2018

Date Published: 31.01.2019

\section{Abstract}

From the past to the present, cinematic narratives reach wide audiences through heroes/subjects who are the carriers of the story they offer. Traces of the interest and attention of the audience are drawn through the subjects of the heroic position. The audience starts the relationship of identity from the hero who is an important act in the narrative. Classical, contemporary or postmodern narratives differ in the situation regarding the construction of the hero, but it is still the subject of the most important action sought in the narrative. In this context, the examination of the heroes in terms of their subject position is important in order to make sense of the cinematic world/journey. In this context, the focus is on the hero of the subject and the object of desire that established, initiated and devised the subject's follow-up. Another important topic discussed in this study is the elements that transform the subject to the accuracy subject to be identified. The Lives of Others film has been analysed in the context of The Actants of Narration" and "Narratives Syntax: Quartet Scheme". The self is another important element in the name of understanding the hero's follower, his change, and his transformation. In this context, as well as the semiological approach, Goffman is another point of view used during the analysis of the micro-sociological concepts that he formulated based on the dramaturgy principles.

Keywords: Cinema, Film Analysis, Actantial Model (The Actants of Narration), Narratives Syntax: Quartet Scheme, Subject, Self. 


\section{Giriş}

Sinemanın öykülü filmler anlatmaya başlamasıyla birlikte film anlatıları içinde izleyicinin odak noktası her zaman için özne konumundaki başkahraman oldu. İnşa edilen mesaj, öykünün taşıyıcısı olan kahramanlar/özneler aracılığıyla geniş kitlelere aktarıldı. Klasik anlatı sinemasının dil ve anlatı yapısı bağlamında film anlatılarına hâkim olan özdeşlik ilişkisi, katharsis ve mutlu son ideolojisi inşa edilen özneler aracılığıyla oluşturuldu. Özdeșleșme, son an kurtuluşu ve romantik aşk mitinin gerçekleşmesi bağlamında bu anlatılar, geniş kitleleri özneler üzerinden peşinden sürükledi.

Aristotelesçi bu yaklaşımın dışında konumlanan çağdaş anlatı sinemasında ise özneler, geleneksel anlatı sineması kodlarından çok farklı bir biçimde tasarlandı. Çağdaş anlatı sinemasında içerik ve biçim farklılaştı. İzleyici, bu kodlara göre inşa edilen kahramanları daha soyut bir izlence ve amaç içinde seyretti. Katharsis ve özdeşleşme unsurlarının reddedildiği bu dil ve anlatı yapısında uzun plan sekanslarla birlikte izleyiciyi rahatsız eden içerik ve biçim kullanımına yönelindi. Yabancılaşma unsurlarının hâkim olduğu ve inşa edilen imajların izleyiciyi düşünsel/entelektüel bir katılıma davet ettiği bu anlatı yapısı içinde sonuç olarak özne konumundaki kahramanlar da farklılaştı.

Dil ve anlatı yapılarında farklılıklar olsa da, içerik ve biçim ilişkisi farklı bağlamlar içinde kullanılsa da bir anlatı içinde en önemli unsur özne konumundaki kahramandır. $\mathrm{Bu}$ bağlamda film anlatılarındaki kahramanların özne konumları açısından irdelenmesi önem taşır. $\mathrm{Bu}$ sorunsal çerçevesinde bu çalışmada film anlatılarını özne konumundaki kahraman üzerinden incelemek amaçlandı. Çalışma boyunca öznenin yitik nesnesi/arzu nesnesi bağlamında izlencesini nasıl kurduğu, anlatı boyunca arayan özne konumundan doğruluk öznesine yani ideal egoya nasıl dönüştüğü gibi araştırma sorularına çeşitli cevaplar arandı.

Niteliksel bir çerçeveye sahip olan bu çalışmada, üretilen bu araştırma sorularına cevap üretebilmek adına iki bakış açısından yararlanıldı. İlk olarak Paris Göstergebilim Okulu'ndan A. J. Greimas'ın "Eyleyensel Örnekçe" ve "Dörtlü Şema" kuramı bağlamında kahramanın özne konumuna ve yitik nesnesi bağlamında ortaya konulan izlencesine odaklanıldı. Özne konumunu, özne konumundaki değişiklikleri ve anlatı boyunca ideal egoya dönüşebilmek adına değișen yitik nesneyi iyi yansıtabileceği düşüncesinden hareketle Başkalarının Hayatı (The Lives of Others-2006) filmi araştırma nesnesi olarak seçildi. Seçilen bu filmden kesitler alındı ve Greimasçı bağlamda çözümlendi.

Greimas'ın göstergebilimsel yaklaşımın yanı sıra Erving Goffman'ın Dramaturjik İlkeleri'nden de yararlanıldı. E. Goffman'ın (2012) Günlük Yaşamda Benliğin Sunumu (The Presentation of Self in Everyday Life) adlı mikro sosyolojik bir bakışla ürettiği çalışmasındaki benlik, performans, rutin, izlenim yönetimi, sahne önü ve sahne arkası kavramları; özne konumunun anlatı boyunca değişen yapısını daha iyi okuyabilmek, öznenin dönüşen benliğini anlayabilmek ve ideal egoyla olan ilişkisini kurabilmek adına çözümlemede kullanıldı. Çalışma bu yöntem ve yaklaşım altında sonuca ulaştırıldı.

$\mathrm{Bu}$ çalışma kuramsal çerçeve-yöntem ve araştırma nesnesinin çözümlenmesi bağlamında temel olarak iki bölümden oluşur. İlk bölümde anlatı kavramı ve 
anlatıya kuramsal yaklaşımlar ele alındı. Böylece Greimas'ın eyleyenler üzerinden tasarladığı bakış açısı temellendirilmeye çalışıldı. Çözümleme kısmına geçmeden evvel Greimas'ın "Eyleyensel Örnekçesi", "Dörtlü Şema" kuramı ve bu bağlamda ortaya koyduğu çeşitli kavramlarla birlikte Goffman'ın “Dramaturjik Yaklaşımı” ve bu eksende üretmiş olduğu kavramlar açıklandı. Son bölümde ise değişen özne konumunu anlama noktasında önemli veriler sunacağl varsayılarak araştırma nesnesi olarak seçilen “Başkalarının Hayatı” filmi göstergebilim ve sosyoloji kaynaklı bakış açısından hareketle çözümlendi.

\section{Anlatı Kavramı ve Anlatıya Kuramsal Yaklaşımlar}

Anlatı, Culler'in $(2007,123)$ belirttiği gibi sadece akademik bir konu değildir. Öyküler duymak ve anlatmak, insanın en temel dürtüsüdür. Barthes'ın (2009, 101) vurguladığı gibi anlatı bütün zamanlarda, bütün yerlerde, bütün toplumlarda mevcuttur. Anlatı, insanlık tarihiyle başlamış olup, dünyanın hiçbir yerinde anlatısı olmayan bir halk da yoktur. Anlatı kavramı farklı düşünürler tarafından farklı biçimlerde tanımlanır. Anlatıyı en kısa ve öz biçimiyle, bir olayın yeniden sunumu olarak tanımlayan Kıran ve Kıran (2007, 100-101), olayın ve yeniden sunumun bir anlatının yaratılması için gerekli temel koşullar olduğunu ileri sürer. Onega ve Landa $(2002,12)$ anlatıyı, zamansal ve nedensel olarak anlamlı bir biçimde bağlantılı bir dizi olayın göstergesel temsili olarak tanımlar. Mutlu'ya göre $(2004,28)$ anlatı zaman içinde gerçekleşen, mantıksal olarak birbirleriyle bağlantılı ve tutarlı bir konuyla bir bütün haline getirilen iki ya da daha fazla olayın aktarılmasıdır. Branigan $(1992,3)$ anlatıyı olayları aktarmak için zamansal ve uzamsal bilgilerin neden-sonuç ilişkisi içerisinde giriş-gelişme-sonuç biçiminde düzenlenmesi olarak tanımlar. Rifat (1999, 15) anlatı kavramının gerçek ya da düşsel olayların, değişik gösterge dizgeleri aracılığıyla anlatılması sonucu ortaya çıkan bir bütün olduğunu ifade eder. Chatman $(2009,19)$ ise anlatıyı bir yapı, açıkça bir bütün olarak niteler. Çünkü anlatı, bir araya gelerek kendilerinden daha farklı bir bütün oluşturan öğelerden, olaylardan ve varlıklardan meydana gelir. Dahası, anlatıdaki olaylar birbirleriyle ilgili ya da karşılıklı etkileşim halindedir.

Farklı tanımlamalardan hareketle anlatı kavramı şu şekilde formüle edilebilir: Zaman içinde gerçekleşen ve birbirleriyle ilişkili olayların neden-sonuç zinciriyle birbirine bağlanarak giriş-gelişme-sonuç düzenlemesi içerisinde bir bütün halinde ötekine aktarılması ve sunulmasıdır. Tarihte anlatı kavramı ile ilgilenen ilk düşünür Aristoteles'tir. Dolayısıyla yapılan bu tanımlamaları Aristoteles'e dayandirmak mümkündür. Onega ve Landa (2002, 9) Anlatı Bilimine Giriş adlı çalışmalarında Aristoteles'in yapıtının özgül bir türe tragedyaya odaklanmıș olsa da, olay örgüsü kullanan bütün türlere uygulanabilecek olağanüstü anlatıbilimsel sezgiler sunduğundan söz eder. Bu bağlamda düşünürün ilk anlatıbilimci olduğunu ifade etmek yanlış olmayacaktır.

Poetika adlı eserinde Aristoteles (2011, 33) tragedyanın bir bütün oluşturan, bir sonuca varan ve zaman içinde belirli bir uzunluğu olan bir eylemin taklidi olduğunu ifade eder. Aristoteles'in bütün olarak belirttiği başlangıcı, ortası ve sonu olan bir şeydir. Düşünür, iyi düzenlenmiş öykülerin rastgele başlayıp bitmemesi; başlangıç, orta ve sonuç gibi bölümlere sahip olması gerektiğini ve en önemlisi olayların iyi düzenlenmesinin zorunluluğunu vurgular. Bu da bizi klasik dramatik yapıya götürür. 
Anlatı kuramı Mutlu'nun belirttiği gibi (2004, 29), “1920’lerin sonlarında Vladimir Propp ve Rus biçimci eleştirmenlerinin çalışmalarıyla kurulan, bugüne değin çok sayıda dilbilimcinin, insanbilimcinin, halkbilimcinin, yazın eleştirmeninin, göstergebilimcininincelemeleriylegeliştirilenveçeşitlianlatılarınyapısalözelliklerini irdeleyip anlatılara ilişkin genel ve açıklayıcı modeller geliştirmeyi amaçlayan bir yaklaşımdır". Yapıtları tek tek ele almayan ve anlatının değişmeyen yapısal düzenini ortaya koymayı amaçlayan bu yapısalcı kuramcılar, anlatıya eklemlenen öğelerin birbirleriyle kurdukları ilişsileri dahası anlatının nasıl kurulduğunu keşfetmeye odaklanır. Örnek olarak yüzlerce Rus masalını inceleyen Propp ve yüz tane Boccacio öyküsünü inceleyen Todorov gösterilebilir. Bu kuramcllar kısaca, inceledikleri anlatılardaki yapısal düzeni ve ortaklıkları ortaya çıkarmaya çalışır.

Tomaşevski, Propp, Şklovski gibi Rus Biçimciler ve Barthes gibi Fransız yapısalcılar, anlatı analizinin yöntem ve tekniklerini geliștiren düşünürlerdir. Onega ve Landa'nın vurguladığı üzere $(2002,15)$ bu kuramcılar, yatay, dikey ya da her iki yönde birden anlatıları çözümler. Başlangıçtan, ortadan ve sondan oluşan bölümler yatay çözümleme açısından söz konusuyken; dikey çözümleme açısından ise çözümleme düzeylerinden söz edilebilir. Anlatı, bir olaylar dizisinin göstergesel temsil edilişiyse, o zaman çözümleme düzeylerinden birinde temsil edilen olaylar incelenecektir. Çözümlemenin başka bir düzeyinde ise, temsil edilişin yapısı incelenecektir. $\mathrm{Bu}$ çözümleme düzeylerinin tanımlanmasına gelindiğinde, anlatıbilim kuramcılarının çoğu zaman görüş ayrılığına düştüğü görülür. Bazıları iki ayrı düzey belirlerken bazıları üç ya da dört düzeyden söz eder. Mieke Bal, anlatının üç temel çözümleme düzeyi bulunduğunu söyler: fabula, öykü ve metin. Tomashevski, yalnızca iki düzeyden söz eder: fabula ve syuzhet. Onega ve Landa ise, üç düzeyden bahseder: metin, öykü ve fabula. Chatman ise $(2008,17)$ anlatının gerekli bileșenlerinin öykü ve söylem olduğunu ileri sürer. Öykü (histoire); içerik ya da olaylar zinciri yani eylemler, olan bitenler, bunlarla birlikte varlıklar diyebileceğimiz karakterler, zaman ve uzamın öğeleri. Söylem ise ifade; yani içeriğin aktarılma yolu. Öykü bir anlatının $n e$ 'sidir, söylem ise nasıl'ı. Chatman'dan farklı olarak Rus biçimciler öykü yerine fabula ve olay yerine syuzhet kavramlarını kullanır. Oluk'unda belirttiği gibi (2008, 25) fabula, olayların kronolojik dizisi olarak tanımlanır. Ne oldu sorusunu yanıtlar. Syuzhet ise "öykü olaylarının, nasıl oluştuğunu, neden oluştuğunu, nerede, ne zaman ve kimler arasında oluştuğunu, bu olayların hangi sırayla anlatılması gerektiğini, öykü bilgilerinin hangilerinin ne miktarda ne zaman verileceğini belirler".

Barthes $(2009,106)$ anlatısal yapıtta üç betimleme düzeyinin ayırt edilmesi üzerinde durur. İşlevler düzeyi (Propp ve Bremond'un benimsedikleri anlamda), öyküleme düzeyi (yaklașlk olarak Todorov'daki söylem düzeyine denk düşer) ve eylemler düzeyi (Greimas'ın anlatı kişilerinden eyleyenler olarak söz ederken benimsediği anlamda). Barthes işlevler düzeyinde en küçük anlatı biriminin tanımlanması gerektiğini vurgular. Ona göre işlev, her birimin anlatının herhangi bir kesitindeki katkısına karşılık gelir. Bir anlatı her zaman işlevlerden oluşur. Bildirişimin olduğu düzeyi ifade eden anlatma düzeyinde gönderen ve gönderilen vardır. Anlatıdaki kişilerin ruhsal varlık olarak değil, eyleme katılan olarak tanımlanması ise eylemler düzeyine karşılık gelir. Eylem alanına katılmalarına göre kişiler sınıflandırılır. $\mathrm{Bu}$ durumda kişiler, birer eyleyen olarak karşımıza çıkar. Eyleyen kavramından hareketle bu çalışmanın yöntemi niteliğinde olan Greimas'ın Eyleyensel Örnekçesi ve ilgili kavramları açıklanmaya başlanılabilir. 


\section{A. J. Greimas: Eyleyensel Örnekçe ve Dörtlü Şema}

Litvanya asıllı Fransız göstergebilimci ve Paris Göstergebilim Okulu'nun kurucusu olan A. J. Greimas, anlamlı bütünlere özgü anlamsal eklemlenişi, anlamsal ayrılıkları ve anlamın üretilişini bir üstdil aracılığıyla yeniden üreterek göstergebilimi açıklar. Rifat'ın belirttiği gibi $(1990,122)$ sadece göstergeleri ya da bildirişim dizgelerini değil, anlamlı bütünleri ele alır. Semiotique narrative et textuelle (Anlatısal ve Metinsel Göstergebilim) adlı 1973 yılına ait kuramsal yapıtında, tüm anlatılar için değișmeyen, aynı özelliklere sahip anlatısal bir yapı ortaya koyabilmeyi amaçlar. Yüzeyden derine odaklanır. Anlamın nasıl oluştuğunu inceleyen Greimas bu bağlamda anlatıların sözdizimsel boyutundaki 6 temel eyleyenle (gönderen/nesne/alıcl/yardımcı/özne/ engelleyici), bu eyleyenlerin farklı söylemlerdeki farklı biçimlerini ele alır (Parsa, 2012, 7). Buna benzer bir anlatısal yapıyı daha evvel V. Propp (2011), Rus halk masallarını inceleyip otuz bir işlev saptayarak yapar. Propp ele aldığı masallardan hareketle her masala uygulanabilecek ortak bir anlatısal yapı ortaya koymaya çalışır. Greimas, V. Propp'un anlatı inceleme yönteminden esinlenir ve Propp'un belirlediği işlevleri bir eyleyen sorunu olarak ele alır. Kıran ve Kıran'a göre (2007, 271-272 eyleyen kavramı ilk kez Fransız dilbilimci L. Tesnier tarafından kullanılır. Ona göre eyleyen, bir sözcede eylemin oluşa etken ya da edilgen biçimde katılan varlık ya da nesne olarak tanımlanır. Genel itibariyle eyleyenler insandır; fakat bazı anlatılarda eyleyenler soyut kavramlar olarak karşımıza çıkar. Zenginlik, toplum, yapı, özgürlük, merhamet, namus vb. Eyleyen, çevresindekilerle ilişkileri açısından özellik kazanan kişidir. Eyleyen, anlatının başından sonuna dek aynı davranıșı sürdürebilir. Yani anlatı boyunca engelleyici olarak öznenin karşısında yer alabilir. Ya da gönderici iken engelleyici konumuna ya da engelleyici iken yardımcı konumuna geçebilir. Bir anlatı içinde birden çok eyleyen tek bir eyleyensel rol de üstlenebilir. Böylece örneğin yardımcı işlevi bir grup tarafından gerçekleştirilebilir. Böyle eyleyenlere ortak eyleyen denilir.

Greimas, eyleyenler üzerine biçimlendirdiği göstergebilimsel anlatı inceleme/ çözümleme modeli olan Eyleyensel Örnekçe'yi (Eyleyenler Şeması) oluşturur ve bu modeli, altı eyleyenin kendi aralarındaki karşıtlık temelinde üçe ayırır. Özne ve nesne karşıtlığından hareketle isteyim ekseni, gönderici ve alıcı karşıtlığından hareketle iletişim ekseni, son olarak yardımcı ve engelleyici karşıtlığından hareketle güç ekseni. Bu eksenler aşağıdaki gibi gösterilebilir.

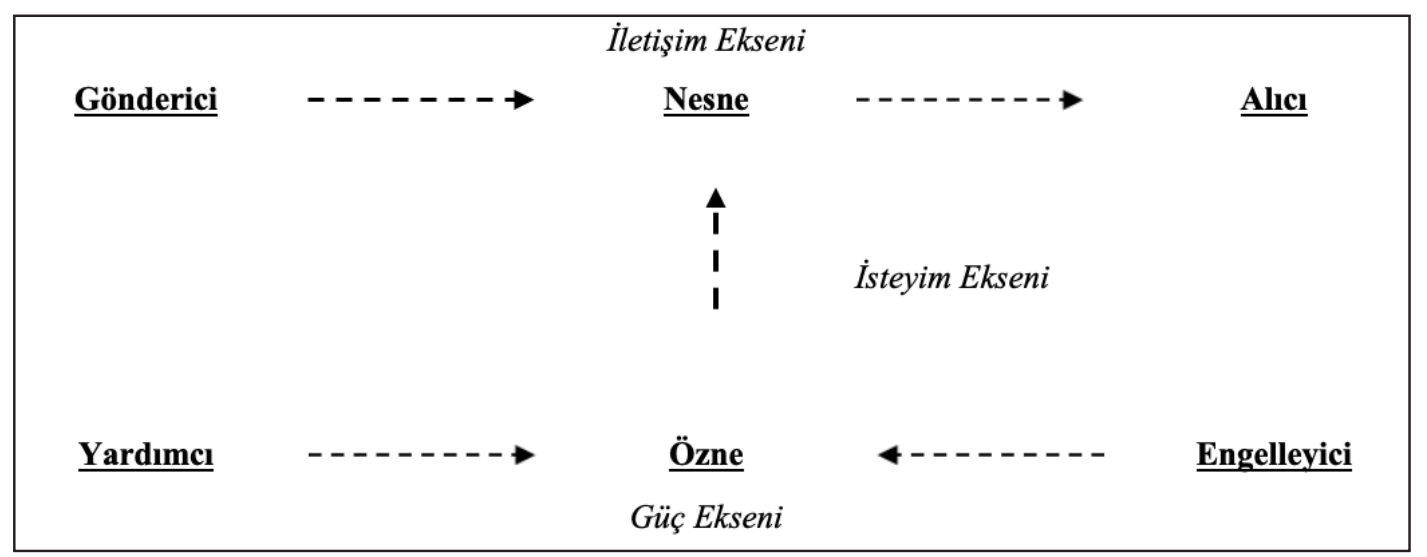

Çizelge 1.1: Eyleyensel Örnekçe ve İletişim/İsteyim/Güç Ekseni 
Kıran ve Kıran'ın ifade ettiği gibi $(2007,273)$ isteyim ekseninde bulunan özne ile nesne kavramları, dilbilgisel öğeler değildir. Anlatı içinde özne, önemli eylemlere katılan başkahramandır. Nesne ise kahramanın anlatı boyunca kendisinde eksik hissettiği ve ulaşmaya çalıştığı somut ya da soyut bir şeydir/kimsedir. Bir eyleyen olarak nesneyi, yitik nesne ya da arzu nesnesi olarak da adlandırmak mümkündür. Yitik nesne, kahramanın izlencesini başlatan önemli bir eyleyendir. İzlence, nesne üzerine kurulur. Bu bağlamda nesne, izlencenin de konusudur. Özne konumundaki kahramanın yitik nesnesi anlatıdan anlatıya farklılaşabilir. Hatta anlatı içinde dahi yitik nesne, kesitler itibariyle farklılık gösterebilir. Bu bağlamda anlatının başlangıcında kurulan izlence (yol/yolculuk), kesitler ilerledikçe yitik nesnenin de değişmesiyle dönüşebilir. Dolayısıyla kahramanın anlatının başlangıcında kendisinde eksik hissettiği yitik nesnesi çıkılan yolculukla farklı bir biçime bürünebilir ve farklılaşabilir. Hatta kahraman, anlatı boyunca ulaşmaya çalıştığı arzu nesnesinden tamamen de vazgeçebilir. Fakat tüm anlatılardaki ortak nokta, özne konumundaki kahramanın kendisinde eksik hissettiği şeyin peşinden gitmesi, izlencesini bu doğrultuda kurmasıdır. Daha evvel belirtildiği gibi bu yitik nesne her zaman için somut bir şey ya da kimse değildir. Örnek olarak bazı anlatılardaki yitik nesne yitirilen gücün, bilginin, sağlığın ya da kimliğin yeniden kazanılması şeklinde ortaya çıkabilir.

Gönderici ve alıcı kavramları iletişim ekseninde karşımıza çıkar. Eksik olan nesneyi bulmakla ilgili özneyi görevlendiren ve göreve çağıran eyleyen göndericidir (Rifat, 2005, 204). Arayış nesnesinin ne olduğunu belirleyen, özneyi yitik nesneyi bulma konusunda harekete geçiren ve görevlendiren eyleyen, göndericidir. Eğer özne, eksik olan nesneyi bulur ve izlencesini başarılı bir şekilde tamamlarsa gönderici tarafından ödüllendirilir. Aksi takdirde eksik olan nesneyi bulamaz ve başarısız olursa gönderici tarafından cezalandırılır. Kıran ve Kıran'ın $(2007,281)$ vurguladığı gibi üstün bir güç olan gönderici her zaman insana benzeyen, somut özellikler taşıyan bir kahraman olmayabilir. Aşk, inanç, doğa vb. kahramanlara görev veren, özneyi eyleme geçiren, özneden güçlü bir eyleyen olarak ortaya çıkabilir. Alıcı ise bu eylemden yarar sağlayan eyleyendir. Öznenin arzu nesnesine ulaşması, birden fazla eyleyen için fayda sağlayabilir.

Özne bazı anlatılarda bir göndericiye gereksinim duymadan harekete geçer. Kendi isteği ve arzusuyla kendi kendisini görevlendirir. Göndericiye ihtiyaç duymadan kendi kendisini eyleten özne, bağımsız ya da özerk öznedir. Özerk özne, hem güçlü hem de bağımsız bir kişiliğe sahiptir. Dolayısıyla bu tarz anlatılarda bir eyleyen, hem gönderici hem özne hem de alıcı rolünü üstlenebilir. Kendi kendisini görevlendiren özne, anlatının sonunda kendi kendisini ya ödüllendiren ya da cezalandıran taraf olarak da konumlanır. Bağımsız ya da özerk özne, Başkalarının Hayatı filmi özelinde üzerinde durulan önemli kavramlardan biridir.

Yardımcı ve engelleyici eyleyenleri ise güç ekseninde karşımıza çıkar. Öznenin kurduğu izlencede ona yardım eden, yitik nesnesine ulaşmasında destek sağlayan eyleyen yardımcıdır. Engelleyici ise yardımcının aksine öznenin yitik nesnesine ulaşmasında zorluk çıkaran, işleri güçleştiren, öznenin izlencesini bölmeye çalışan ve özneye karşı çıkan eyleyendir. Anlatılarda bazen her iki eyleyen mevcutken, bazı anlatılarda bazen sadece biri ortaya çıkar. Göndericinin ve nesnenin somut ya da soyut olması gibi burada da aynı durum söz konusu olabilir. Yardımcı bazen doğaüstü bir güç, bazen de sihirli bir kılıç olabilir. Engelleyici ise bazen yol vermez 
bir nehir, bir dăg, bir fırtına bazen de bilgi eksikliği ya da bir ejderha olarak karşımıza çıkabilir. Bir anlatıda öznenin izlencesini başarılı bir şekilde devam ettirebilmesi ve sonlandırabilmesi yardımcının ve engelleyicinin ne kadar güçlü olduğuyla doğru orantılı olabilir. Öznenin engelleyicileri ne kadar güçlüyse başarılı olma ihtimali o kadar düşerken, yardımcıların üstünlüğü özneyi yitik nesnesine bir adım daha yakınlaştırmaktadır.

Öznenin anlatıdaki nesnesiyle olan ilişkisini Kıran ve Kıran $(2007,273)$ şu şekilde ifade eder:

1. Genellikle anlatının başında özne ne nesneyle beraberdir ne de ondan ayrıdır: (Ö,N).

2. Özne nesnesinden ayriysa: (ÖUN).

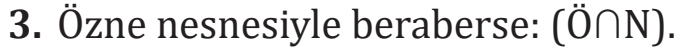

Bazı anlatıların başında özne, nesnesiyle ne beraberdir ne de ondan ayrıdır. Esasında bu durumda özne ve nesne arasında herhangi bir ilişki yoktur denilebilir. Anlatı ilerledikçe yitik nesnenin eksikliğini hisseden özne konumundaki kahraman, nesne üzerinden izlencesini kurar. Bu bağlamda anlatının başında ve devamında nesnesinden ayrı olan özne, nesnesiyle ayrışımsal bir ilişki içindedir (ÖUN). Genellikle mutlu sonla biten anlatılarda kesitler ilerledikçe özne, nesnesine sahip olur. Böylece anlatının başında nesnesiyle ayrışımsal bir ilişki içinde olan özne, anlatının devamında nesnesine sahip olur ve onunla bağlaşımsal bir ilişki içine girer $(O ̈ \cap N)$. Böylece anlatı, arayışın nesnesinin bulunmasıyla sona erer.

Greimas'ın "Dörtlü Şema” yaklaşımı, çalışmanın film anlatısı çözümlemesinde kullanılan diğer bir yöntemdir. Anlatının dörtlü şeması, Eyleyensel Örnekçe'den farklı bir yapı ortaya koyar. Kıran ve Kıran'ın belirtiği gibi (2007, 304), Greimas beş aşamalı yapıyı basitleştirir. Çözüm ve bitiş bölümlerini birleştirir. Eyleyenlerin değişimine ve dönüşümüne odaklanır. Dört aşamada edindikleri ya da edinemedikleri özelliklere ya da becerilere göre inceler.

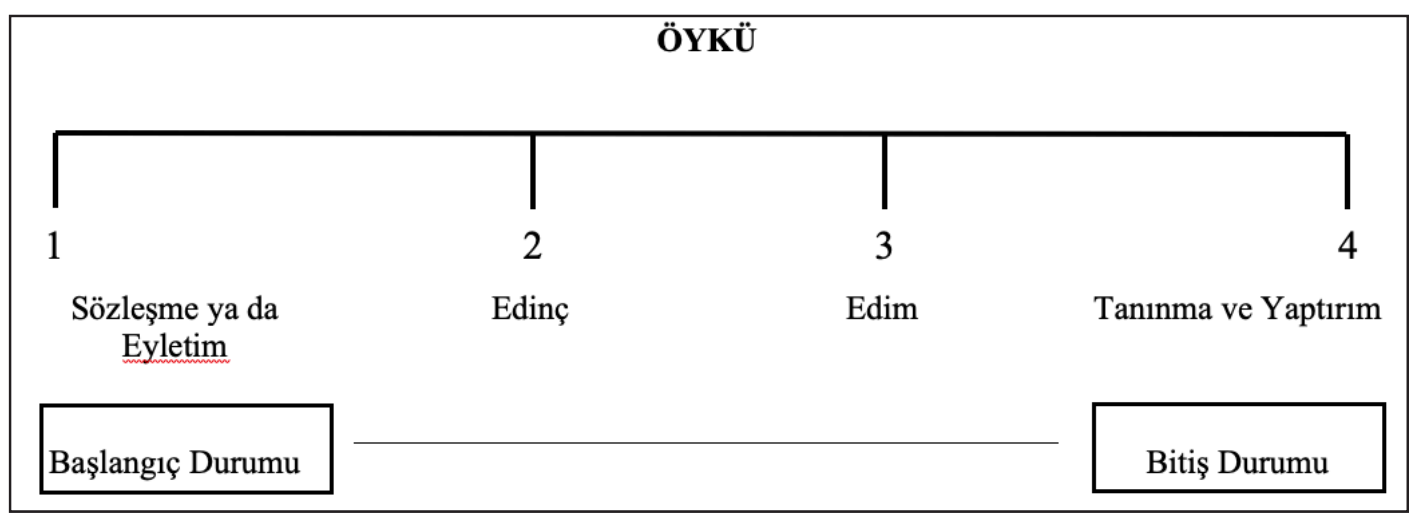

Çizelge 1.2: Anlatının Dörtlü Şeması

Anlatının dörtlü şemasındailk aşama sözleşme ya da eyletimdir. Bu aşamaya başlangıç durumu da denilebilir. Bu aşamada gönderici ile özne arasında bir sözleşme yapılır. Bu sözleşmenin bir gereği olarak özne izlencesini belirler ve anlatı böylelikle başlar. Daha evvel belirtildiği gibi gönderici belli bir amaç doğrultusunda özneyi görevli kılar. Bu aşama bundan dolayı yaptırtma eylemi içerir. Özne bu sözleşmeyi bazen kendisinden üstün bir güçle bazen de bizatihi kendisiyle yapar. Öznenin özerk olduğu anlatılarda, sözleşmenin gereği olarak ortaya konan ödül ve ceza yine özne tarafından 
belirlenir. İkinci aşama edinç aşamasıdır. Kıran ve Kıran'ın $(2007,305)$ ifade ettiği gibi bu aşamada özne; göndericiyle yaptığı sözleşme uyarınca yitik nesnesine ulaşmak adına gerekli ve zorunlu dönüşümleri geçirir ve bir eyleme geçebilmek adına ihtiyaç duyduğu birtakım yetenekleri kazanır. "Anlatı göstergebilimi, bu yetenekleri kiplik kavramına bağlayarak dörde ayırır: yapmak zorunda olmak, yapmayı istemek, yapabilmek (güç) ve yapmayı bilmek (bilgi)". Bu bağlamda karşımıza arayan ve doğruluk öznesi kavramları çıkar. Arayan öznede, istemek kipliği ilk sıradadır. Arayan özne, bilgiden ve güçten yoksundur. Arayan özne bilgiye ulaştıkça istemek kipliğinin yerini bilmek alır ve özne doğruluk öznesine dönüșür. Doğruluk öznesi isteyen, bunun sonucunda bilgi ve güç sahibi olandır. Dolayısıyla artık özne, bilgisinin ve gücünün farkındadır. Anlatılarda çok az şey başlangıçtakilerle aynıdır. Birçok şey başlangıç-bitiş arasında geçen süre zarfında değişip dönüşür. Bu nedenle anlatının öznesi, arayan özne ve doğruluk öznesi kavramları arasında anlatının başlangıcından bitişine dek sürekli salınıp durur. Genel itibariyle anlatının bitiş durumunda özne bu üç özelliğe ulaşır. Birçok anlatıda genellikle öznenin nesnesine ulaşması istek, güç ve bilginin öznenin bedeninde somutlaşması ile mümkün olur.

Üçüncü aşama edim evresidir. Bu evrede özne; edinç evresinde edindiği güç, yetenek, bilgi gibi çeşitli dönüştürücü özellikleri eyleme çevirir. Özne, nesnesine ulaşmak için dönüştürücü eylemlere bu aşamada başlar. İstek, güç ve bilgiye edinç evresini geçerek ulaşan özne, bu evrede edindikleriyle nesnesine ulaşmaya çalışır. Edinç evresini başarılı bir şekilde geçiren özne, edim evresine geçerek genellikle yitik nesnesine ulaşır. Tam tersi bir durumda ise yani özne edinç evresini tamamlayamaz ve gerekli özellikleri edinemezse edim evresinde başarılı olamayacak, dolayısıyla nesnesiyle ayrışımsal ilişkisini sürdürmek zorunda kalacaktır. Bu evrede yardımcıların ve engelleyicilerin özne açısından büyük önemi vardır. Çünkü bu eyleyenlerden herhangi birinin etkili olması, öznenin nesnesine giden yolunu biçimlendirir. Anlatının dörtlü şemasında son birim ise, tanınma ve yaptırımdır. Diğer bir deyişle anlatının bitiş durumudur. Edinç aşamasında istek, güç ve bilgiye ulaşarak edim evresinde dönüştürücü eyleme geçen özne, nesnesine ulaşır. Daha önce belirtildiği gibi edinç evresi başarıyla sonlandırılmazsa edim evresinde özne başarısız olur. Tanınma ve yaptırım aşamasına ödül ve ceza aşaması demek de mümkündür. Edim evresinde başarılı olan özne nesnesine ulaşır ve son aşamada ödüllendirilir. Aksi takdirde nesnesine ulaşamaz ve cezalandırılır. Öznenin ödül-nesnesine ulaşması ya da cezalandırılması edinç evresini başarılı bir şekilde tamamlayıp tamamlayamamasına, yardımcılara, engelleyicilere ve edim evresindeki dönüştürücü eylemine bağlıdır.

\section{E. Goffman: Dramaturjik illkeler ve Kavramlar}

Goffman, sembolik etkileşimcilik içinde benlik üzerine çalışan isimlerden biridir. Onun çalışmaları makro yapılar yerine bireye odaklanır. Yani mikro sosyolojik bir bakış açısıyla toplumdan ziyade bireye yöneliktir. Goffman (Ritzer: 2013a, 375-376), insani olan benlikler ile toplumsallaşan benlikler arasında önemli uyuşmazlıkların olduğunu ileri sürer. Ona göre bu gerilimin kaynağı insanların bizden ne yapmamızı bekledikleri ile spontane olarak ne yapabileceğimiz arasında yaşanır. Bu bağlamda birey kararsızlıklar yaşar; çünkü içimizden geldiğinden ziyade toplumun bizden beklediği davranışları üretmemiz istenir. Goffman'a göre benlik bu inişler çıkışlar sonucu oluşur. Ona göre benlik, eyleyenin mülkiyetinde değildir. Eyleyen ve izleyici arasında yaşanan iletişimin ve dramatik etkileşimin bir karşılığıdır. Bu çerçevede benlik, eyleyenin performans gerçekleştirdiği sahnede ortaya çıkar. Poloma'nın 
da vurguladığı üzere $(2012,217)$ Goffman benliği kapalı bir sistemin ürünü olarak görür. Ona göre benlik, yazılmamış bir üründür ve toplumsal kişilerin etkinliklerini ayrıntılı olarak belirler.

Goffman'ın (2012, 13) dramaturjik yaklaşımının temel çıkış noktası aktörlerin davranışlarının çözümlenmesi ve insanlararası etkileşim ve iletişim üzerinedir. Düşünür bu etkileşimi çözümlerken tiyatro ve drama benzetmesinden yola çıkar. Ona göre hayat bir sahnedir. İnsanlar da o sahnede (yaşam sahnesi) toplumsal metinlere göre rol icra eden bir aktördür. Bu bağlamda Goffman, aktör ve izleyici arasındaki etkileșimden hareketle dramaturjik ilkeleri ortaya koyar. Onun görüşüne göre (2012, 28-33, 137), yaşam sahnesinde rol yapan aktörlerin davranışları ya da etkinlikleri "performans" olarak görülür ve kavramsallaştırılır. Bir aktörün diğer bir eyleyeni ya da izleyiciyi etkilemeye yönelik davranışları ve tüm faaliyetleri performans olarak tanımlanır. Bu performans sırasında aktörler, birtakım unsurları vurgularken birtakım unsurları da gizlemeye ya da bastırmaya çalışır. Eğer saklanmak ya da bastırılmak istenen unsurlar ortaya çıkarsa ya da izleyicinin dikkati bu unsurlara kayarsa aktörün icra ettiği performans tehlikeye düşebilir. Aksayabilir hatta performans sona ermek durumunda kalabilir. Bu aşamada karşımıza "yıkıcı bilgi" kavramı çıkar. Performansın temeli bilgi denetimine dayanır. Bilgi denetiminin temel amacı ise aktörün gizlemek ve bastırmak durumunda kaldığı yıkıcı bilginin ortaya çıkmamasıdır. Yıkıcı bilginin ortaya çıkması ya da izleyici tarafından ele geçmesi, aktörün izleyiciyle etkileşimini sıkıntıya sokabilir.

Goffman'a göre sahnede performans icra eden aktörler, toplumsal metinlerden beslenir. Bu performanslar toplumsal yapı, dekor ve metin kaynaklıdır. Ona göre eyleyen konumundaki bireyler belirli sahnelerde $(2012,28)$ uygun "rutinler" arasından uygun metinleri seçerek performanslarını gerçekleştirir. Rutin kavramıyla düşünürün ifade etmek istediği toplumsal metinlere dayalı uygun eylem kalıplarıdır. Sahneler değişir, performanslarda uygun eylem kalıpları seçilerek bu sahnelerde gerçekleştirilir. Uygun eylem kalıplarını seçen aktörler, kendilerini ötekine taktim eder ve performansını bu takdimi yönetmek üzerine kurar. Bu davranışın temelinde belirli bir izlenimi oluşturmak ve yönetmek vardır. Bu bağlamda düşünürün diğer bir kavramı "izlenim yönetimi” karşımıza çıkar. Ritzer'in de belirttiği gibi (2013b, 234) insanlar, etkileșime girdiklerine makbul olan birtakım performanslar sergiler. Makbul performanslar makbul benliği sergilemek, dolayısıyla oluşturulan izlenimi yönetmek ve denetlemek içindir. İzlenim yönetimi, aktörün saklamak durumunda kaldığı yıkıcı bilginin de ortaya çıkmasını engelleyecek bir performans çeşididir. Goffman'a göre (Layder, 2010, 90; Berberoğlu, 2009, 171-172) insanlar farklı kişilik özelliklerine sahiptir. Farklı anlarda ve koşullarda farklı insanlara (izleyiciye) kişiliklerinin farklı özelliklerini sergiler ya da sergilemek durumunda kalır. Öteki üzerinde bilinçli bir şekilde belirli izlenimler inşa etmeye, bu izlenimleri şekillendirmeye ve yönetmeye çalışır. Nihai amaç kişinin içinde bulunduğu durumu kendi lehine kontrol altına alabilmek, toplumsal metinlere uygun makbul performanslar sergileyebilmektir.

"Sahne önü" ve "sahne arkası" kavramları Goffman'ın (2012, 112) dramaturjik ilkeler bağlamında ortaya koyduğu ve bu çalışma bağlamında yararlanılan son iki kavramıdır. Aktörlerin uygun rutinlerden yani uygun eylem kalıplarından ve kamusal senaryodan/toplumsal metinlerden beslenerek ortaya koyduğu performansın icra edildiği uzam, sahne önüne karşılık gelir. Bu uzamda kişiden/aktörden hangi uygun/ makbul davranış bekleniyorsa, bu davranışlar sergilenir ve tekrar edilir. Uygun 
davranışlar kabul edilen bir izlenimi de beraberinde getirir. Dolayısıyla sahne önünde izlenim yönetimi başat bir performans olarak karşımıza çıkar. Bu uzam, toplumsal metinler tarafından inşa edilmiştir. Eyleyenin bizatihi kendisinin tasarladığı bir alan değildir. $\mathrm{Bu}$ bağlamda kamusal senaryoya ters düşebilecek eylemlerden ve davranışlardan uzak durulur. İnşa edilen izlenimi zedeleyecek yıkıcı bilgi bu uzamda büyük bir titizlikle korunur, toplumun izin verdiği roller icra edilir. Sahne arkası kavramı ise yıkıcı bilginin saklanmak zorunda kalınmadığı, kamusal senaryoya göre performansların icra edilmediği ve edilmek zorunda olunmadığı, daha kendiliğinden ve özerk eylemlerin ortaya konduğu uzama karșllık gelir. Sahne önünde saklanan, gizlenen ve bastırılan birtakım davranışlar ya da gerçekler, bu alanda rahatça ortaya çlkar. Aktör bu alana izleyicinin girmesini istemez; çünkü sahne önünde sergilediği makbul performansların zedelenmesini istemez.

\section{Kahramanın Değișen Özne Konumu}

\subsection{Filmin Künyesi}

\begin{tabular}{|l|l|}
\hline Filmin Adı & Başkalarının Hayatı (Das Leben der Anderen-The Lives of Others) \\
\hline Yönetmen & Florian Henckel von Donnersmarck \\
\hline Senaryo & Florian Henckel von Donnersmarck \\
\hline Yapımcı & Quirin Berg, Max Wiedemann \\
\hline Görüntü Yönetmeni & Hagen Bogdanski \\
\hline Vizyon Tarihi & 2006 \\
\hline Süre & $137 \mathrm{dk}$. \\
\hline Oyuncular & $\begin{array}{l}\text { Ulrich Mühe (Gerd Wiesler), Sebestian Koch (Georg Dreyman), } \\
\text { Martina Gedeck (Christa-Maria Sieland), Ulrich Tukur (Anton Grubitz), } \\
\text { Thomas Thieme (Bruno Hempf), Volkmar Kleinert (Albert Jerska). }\end{array}$ \\
\hline
\end{tabular}

\subsection{Filmin Öyküsü}

Florian Henckel von Donnersmarck'in yönetmenliğini yaptığı Başkalarının Hayatı adlı film anlatısı, Berlin Duvarı'nın yıkılmasından 5 yıl önce (1984) Doğu Almanya'da geçer. Anlatının kahramanı olan Yüzbașı Gerd Wiesler, Devlet Güvenlik Bakanlığı'na bağlı Stasi adlı bir istihbarat servisinde çalışır. Görevi hükümete karşı olan muhalif unsurları tespit etmek ve raporlamaktır. Anlatının devamında tiyatro yazarı Georg Dreyman'dan şüphelenilir. Devlet Güvenlik Bakanı tarafından Wiesler'a, oyun yazarı Georg Dreyman ve tiyatro sanatçısı sevgilisi Sieland'ın evlerini dinleme ve onların aleyhine kanıt toplama görevi verilir. Bu görev esnasında başkalarının hayatına dâhil olan, yaşadığı birtakım olaylarla değişmeye ve dönüşmeye başlayan Wiesler, oyun yazarı Dreyman'a ait bazı gerçekleri örtbas etmeye başlar.

\subsection{Film Çözümlemesi}

Anlatı, siyah ekran üzerinde beyaz yazılarla başlar. Beyaz yazılarla birlikte anlatının geçtiği zamana, mekâna ve politik içeriğe dair çeşitli bilgiler aktarılır.

“1984, Doğu Berlin. Düşünce özgürlüğünden çok uzak. Doğu Almanya halkı, Doğu Alman Gizli servisi Stasi tarafından sıkı denetim altında tutulmaktadır. 100.000 çalışanı ve 200.000 muhbiri Proletarya Diktatörlügü’nü korumaktadır. Amaç ise her şeyi bilmektir”.

Film anlatısı, Berlin Duvarı'nın Almanya'yı ikiye böldüğü bir dönem içinde Doğu Almanya'da başlar. Özne konumundaki kahraman, istihbarat servisi içinde çalışan bir personel olarak izleyicinin karşısına çıkar. Amacı, sistemin her şeyi bilmesine ve tüm muhalif unsurları tespit ederek saf dışı bırakmasına yardım etmektir. İzleyici, özne konumundaki kahramanla daha ilk kesitte tanışır. Yüzbaşı Gerd Wiesler 
(özne), Devlet Güvenlik Bakanlığı'na bağlı cezaevinin sorgu odasında bir mahkûmu sorgularken görülür. Özne, alt açıyla iktidarı ve gücü temsil eden biri olarak taktim edilir. Böylece iktidarın içinde konumlanan özneye dair izleyicinin zihninde bir şeyler canlanmaya başlar. Yüzbaşı'nın sorgu odasındaki jest ve mimiklerinden ve söylemlerinden göreviyle ilgili bilginin sahibi olduğu ve iktidarı temsil ettiği açıkça görülür. Aynı zamanda Doğu Alman Gizli Servisi Stasi'ye bağlı yüksekokulda ders de veren özne; sorgu sırasında yaşadıkları, tutulan kayıtlar ve devletin düşmanları olarak görülen kişilerin uygulamaya çalıștıkları taktik ve stratejiler hakkında öğrencilere çeşitli bilgiler aktarır.

\begin{abstract}
"Masum bir tutuklu uğradığı haksızlıktan dolayı gittikçe daha çok öfkelenir. Bağırır ve asabileşir. Suçlu biri ise saatler geçtikçe sakinleşir ve konuşmaz. Ya da ağlar. Çünkü neden orada olduğunun bilincindedir. Birinin suçlu olup olmadığını öğrenmenin en iyi yolu gücü tükenene kadar sorguya çekmektir"
\end{abstract}

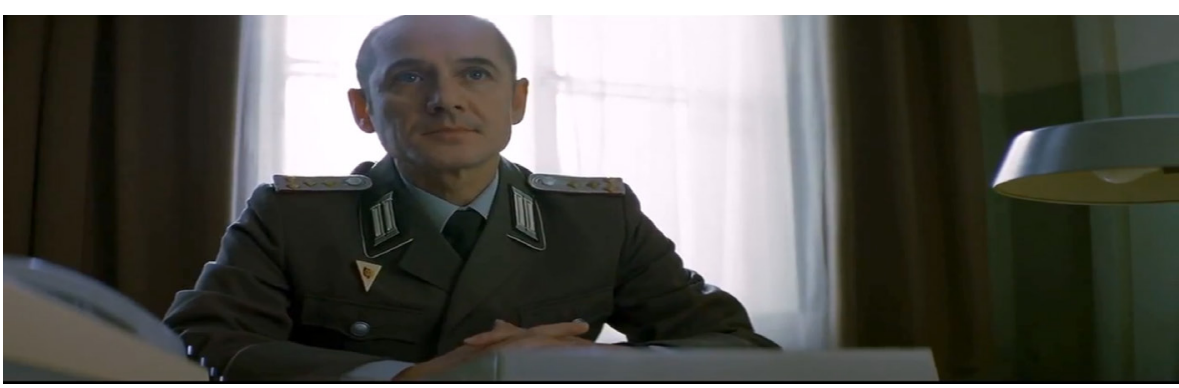

Resim 1: Yüzbaşı Gerd Wiesler, iktidarı ve gücü temsil eder. Karakterin jest ve mimikleri dışında kullanılan sinematografik dil de (alt açı-yüceltme) bunu destekler.

İsteği, gücü ve bilgisi olan özne, doğruluk öznesi olarak ifade edilir. Fakat kahraman, anlatının başında henüz doğruluk öznesi değildir. Yaptığı işle ilgili bilgiye ve güce sahip olmak, kahramanı doğruluk öznesine dönüştürmez. Bu bağlamda izleyicinin rahatlıkla özdeşlik kurabileceği ideal bir ego da değildir. Kesitler ilerledikçe kahramanın iktidarla olan ilişkisi ve iktidar içindeki konumu, izleyicinin onun bakışıyla anlatıya girmesine izin vermez. Fakat bu durum özne bakımından değişimlerin ve dönüşümlerin yaşanmasıyla ilerleyen sekanslarda farklılık gösterir.

İlk kesit itibariyle özne konumundaki kahraman hakkında çeşitli bilgiler sunulur. Fakat bu kesitte öznenin yitik/arzu nesnesi ortaya çıkmaz. Bu bağlamda anlatının başında özne, nesnesiyle ne beraberdir ne de ondan ayrıdır (Ö, N). Diğer bir deyişle özne ve nesne arasında ne ayrışımsal ne de bağlaşımsal bir ilişki vardır.

Anlatı ilerler. Kültür Dairesi Başkanı Grubitz’le özne konumundaki Yüzbaşı'nın yanı sıra anlatı içinde önemli diğer eyleyenler olan Kültür Bakanı Bruno Hempf, oyun yazarı Georg Dreyman ve Dreyman'ın birlikte olduğu aktrist Christa Maria Sieland tiyatro kesitinde ortaya çıkar. Tiyatro oyununun yazarı Georg Dreyman'dır. Bu oyunu izlemeye Kültür Bakanı'nın yanı sıra Kültür Dairesi Başkanı'yla Yüzbaşı'da gelir. Kültür Bakanı Bruno Hempf, Kültür Dairesi Başkanı Albay Grubitz'e Georg Dreyman hakkında şüphe uyandıran bir şeyler olduğunu, haftaya Perşembe Dreyman'da gerçekleşecek olan partiye kadar gizli ve küçük bir dinleme tertibatının kurulmasını ve sadece kullandığı odalara bu cihazların yerleștirilmesini emreder. Albay Grubitz'de bu işle ilgilenmesi için Yüzbaşı'yı görevlendirir. Böylece tiyatro kesiti itibariyle 6 temel eyleyen, öznenin yitik nesnesi ve izlencesi ortaya çıar. 


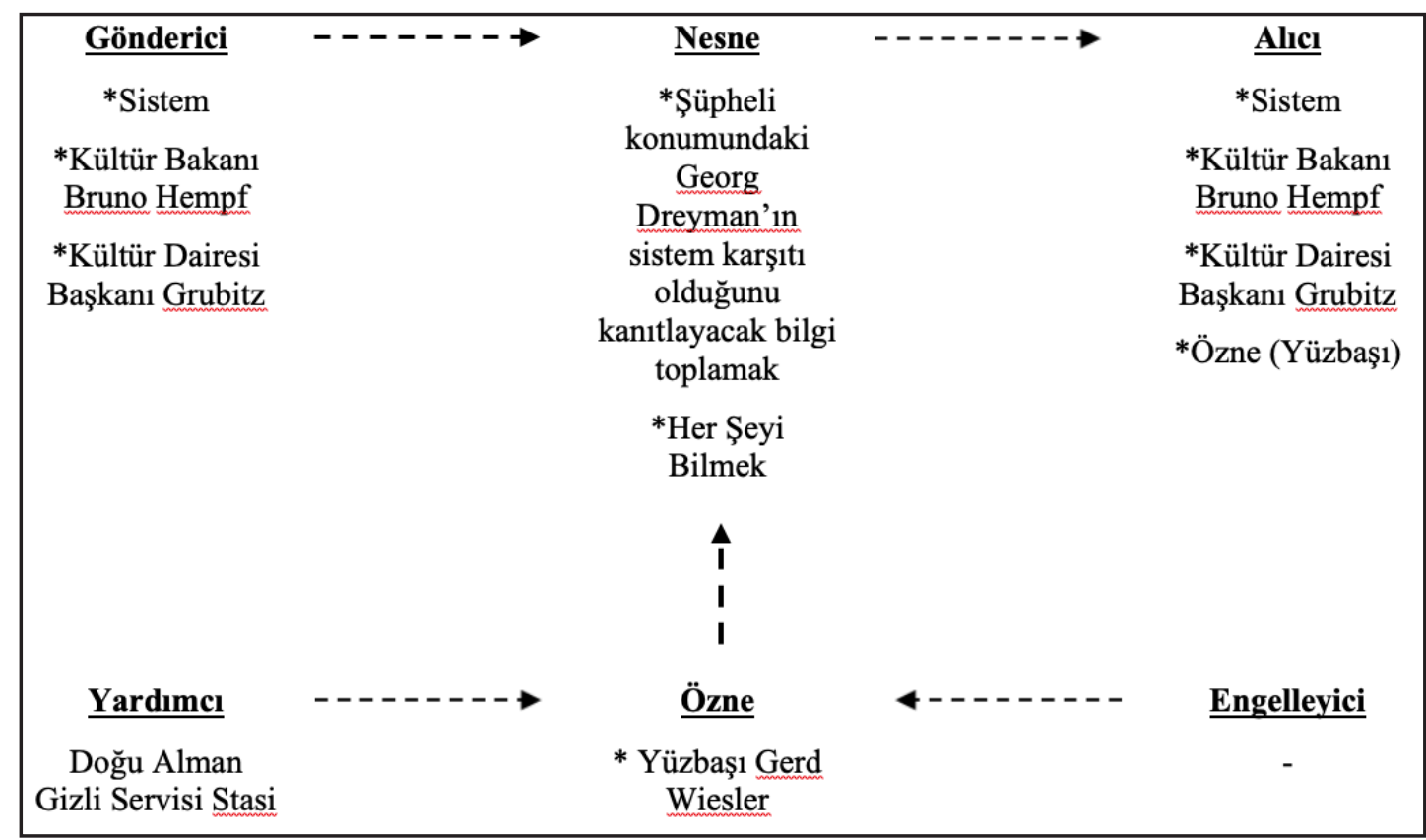

Çizelge 1.3: Tiyatro Kesitinin Eyleyensel Örnekçesi

Özne konumundaki Yüzbaşı Wiesler'ın yitik/arzu nesnesi, şüpheli görülen oyun yazarı Dreyman'ın sistem karşıtı olduğunu kanıtlayacak bilgiye ulaşmaktır. Öznenin göndericisi konumunda açık bir şekilde Kültür Bakanı ve Kültür Dairesi Başkanı vardır. Örtük olarak ise sistemin kendisi asıl gönderici konumundadır. Anlatının açılış sekansında da belirtildiği gibi sistemin amacı "her şeyi bilmektir". Bu yitik nesne bağlamında özne konumundaki Yüzbaşı, izlencesini kurar. Özne, bağımsız ya da özerk özne değildir. Bir göndericisi vardır ve bu otorite/yapı tarafından görevlendirilir. Alıcı eyleyeni olarak gönderici konumunda olan eyleyenler bulunur. Bu operasyon sonucunda Kültür Bakanı, Kültür Dairesi Başkanı ve Yüzbașı, terfi alabilir. Sistem tarafından ödüllendirilebilir. Fakat en nihayetinde sistemin kendisi yani sosyalizm asıl fayda sağlayacak olan taraftır. Yüzbașı'nın yardımcısı konumunda yani dinleme tertibatını Dreyman'ın evine kuran Stasi çalışanları vardır. Öznenin engelleyici konumunda ise ilk kesitler itibariyle herhangi bir eyleyen yoktur. Bir anlatı içinde öznenin yardımcılara sahip olması ve engelleyicilerinin olmaması genellikle, öznenin yitik nesnesine ulaşmasında önemli bir rol oynar.

Anlatının dörtlü șeması bağlamında değerlendirildiğinde sözleșme ya da eyletim aşaması, gönderici konumunda olan ortak eyleyenlerle özne konumundaki Yüzbaşı arasında yapılan bir sözleşme/anlaşma sonucu başlar. Ulaşılması gereken nesne, çok somut ve açıktır. Bu noktadan hareketle Yüzbaşı Wiesler'ın nesnesine ulaşabilmesi adına edinç aşamasına geçtiği görülür. Öznenin ve yardımcılarının Dreyman'ın evine dinleme tertibatı kurması ve konuşulan her şeyin rapor haline getirilmesi, ayrıca Yüzbaşı'nın Dreyman hakkında bilgi toplaması edinç aşamasındaki çabalar ve ulaşılması gereken bilgiler olarak değerlendirilebilir. 


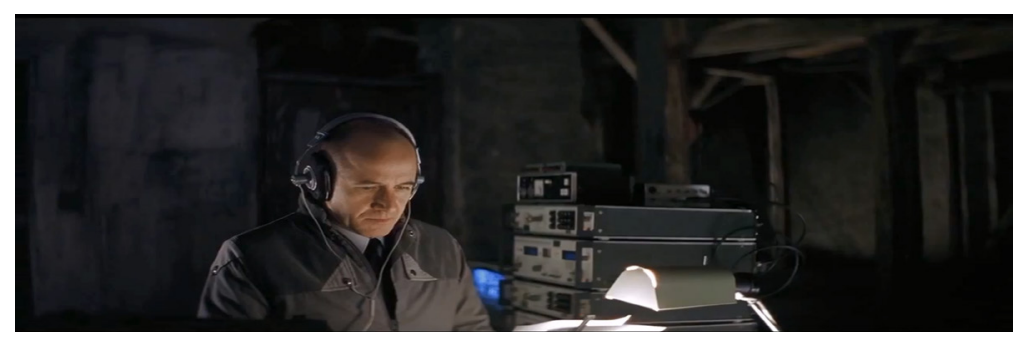

Resim 2: Özne konumundaki Yüzbaşı Gerd Wiesler'ın Dreyman’ın evini dinlediği sahne.

Anlatı ilerledikçe Yüzbaşı Wiesler’ın, Dreyman’ın evini dinlemeye ve bu bağlamda rapor tutmaya devam ettiği görülür. Fakat kesitler ilerledikçe başkalarının hayatına dinleme yoluyla katılan ve onlarla empati kuran öznenin, değişip dönüşmeye başladığı görülür. Özneyi değiştiren ilk unsur olarak Kültür Bakanı'nın Dreyman'ın kız arkadaşı olan aktrist Christa Maria Sieland ile olan ilişkisini Dreyman'a gösterdiği sahne örnek verilebilir. Yüzbaşı, "acı gerçeklerle yüzleşme zamanı" diyerek Dreyman'ın kapı zilini tavan arasındaki düzenek yardımıyla defalarca çalar. Birçok kez çalan kapıyı açmaya giden Dreyman, kapı zilinin takılı kaldığını düşünerek apartmanın dış kapısını açar. Christa Maria Sieland'ın bakanın arabasından indiğini ve üstünü başını düzelttiğini görür. Diğer bir kesitte Yüzbaşı, Dreyman'ın evine girer ve daha sonraki kesitte Dreyman'ın Brecht kitabını aldığı ve okuduğu görülür. Öznenin Brecht okuduğu sıradaki yüz ifadesinden dönüşmeye başladığı anlaşılır. Kahramanı dönüştüren diğer unsurları anlatı ilerledikçe izleyici görmeye başlar. Dreyman, Beethoven'ın "Appassionata”sını piyanoda çalar ve "bu müziği gerçekten dinlemiş biri kötü bir insan olabilir mi" diye sorar. Yüzbaşı Whisler'ın Beethoven'ı dinlediği ve gözünden yaş geldiği görülür. Diğer bir sekansta Yüzbaşı, sahne yaşamını sürdürebilmek için Kültür Bakanı'yla kendisini görüşmek zorunda hisseden Christa Maria Sieland ile bir iletişim mekânında bir konuşma yapar. Bu konuşma sonucunda Sieland, Bakan'la görüşmez. Bu bağlamda özne konumundaki Yüzbaşı, Dreyman'ın ve Sieland'ın yardımcı eyleyenine dönüşür.
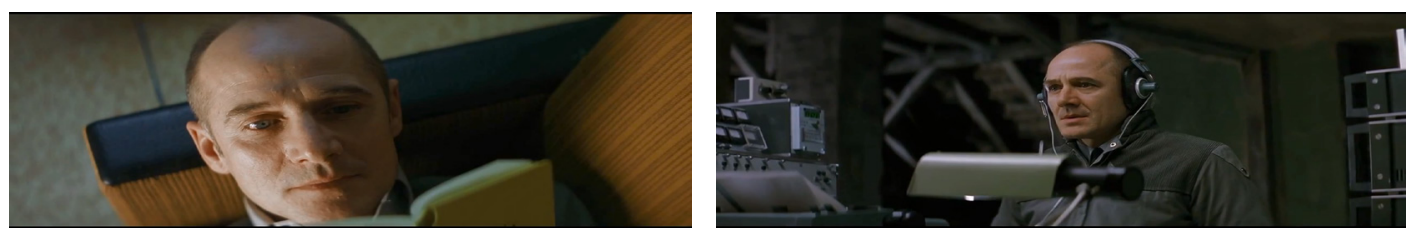

Resim 3-4: Kesitler ilerledikçe başkalarının hayatına dinleme yoluyla katılan ve onlarla empati kuran öznenin, değişip dönüşmeye başladığı görülür.

Tüm bu unsurlar özneyi, arayan özneden doğruluk öznesine dönüştürmede başat rol oynar. Anlatının başında özneyle özdeşlik ilişkisini başlatamayan izleyici, kahramanla özdeșlik kurmaya başlar. İsteği sonucunda bilgiyi ve gücü bünyesine katmaya başlayan kahraman, doğruluk öznesine dönüşür. Dreyman'ı dinlemek ve şüpheli konumunu doğrulayacak bilgileri rapor etmek olan yitik nesnesine ulaşmaktan vazgeçer. Çünkü kesitler ilerledikçe bilgiye sahip olan kahraman bu bağlamda izlencesini de sonlandırır. Bu bağlamda özne konumundaki Yüzbașı'nın yeni bir yitik nesnesi ortaya çıkar. Özne artık bağımsız ya da özerk öznedir. Yani kendi kendisinin göndericisi konumundadır. Herhangi bir göndericiye bağlı kalmadan, kendi kendisini eyleten rolündedir. 


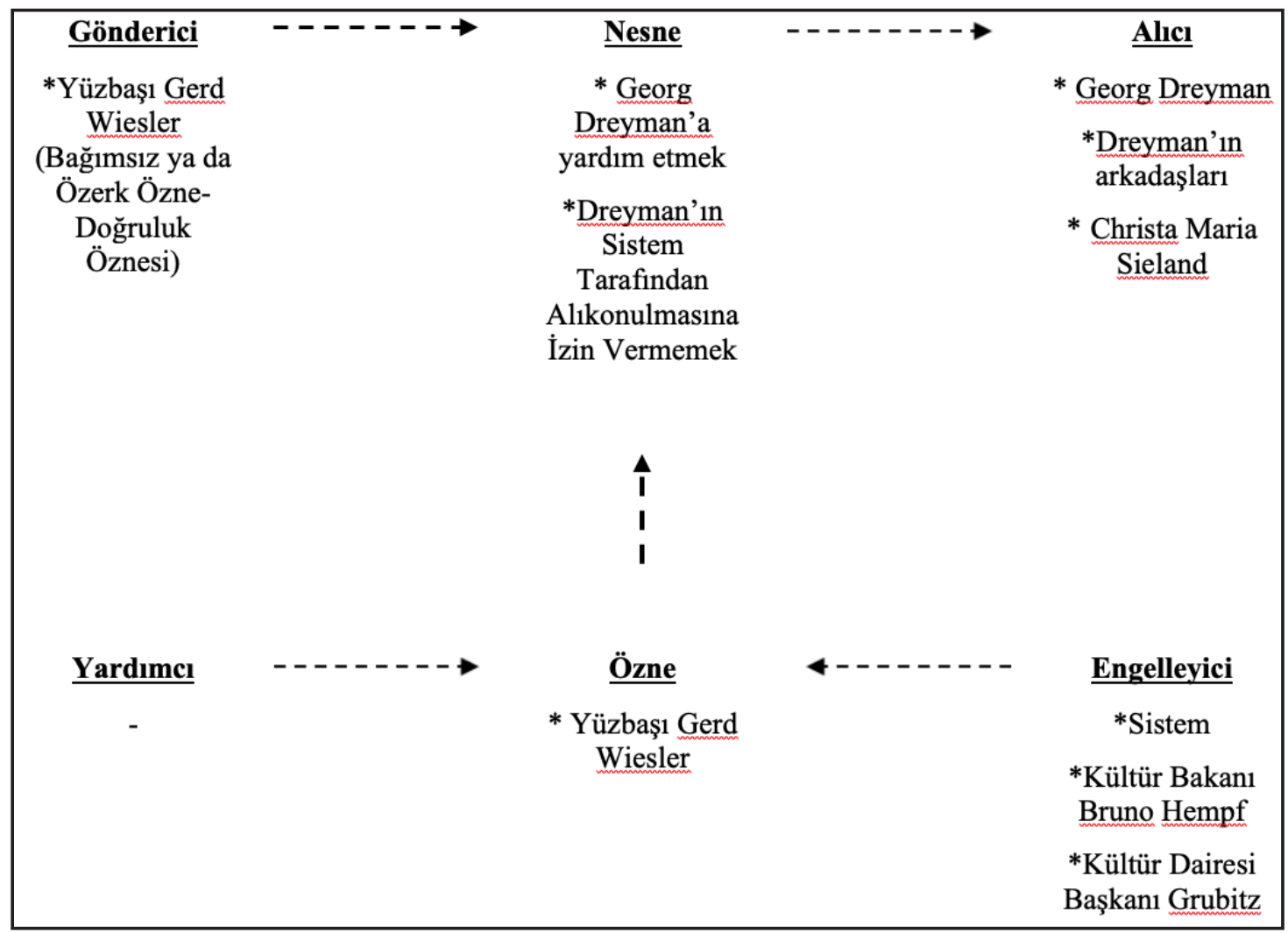

Çizelge 1.4: Özne Konumundaki Kahramanın Yeni Yitik Nesnesi ve İzlencesi

Özne konumundaki Yüzbaşı Wiesler'ın yeni yitik nesnesi Georg Dreyman'a yardım etmek ve sistemin onu hapsetmesine engel olabilmek şeklinde ortaya çlkar. Özne, bu yeni nesne üzerinden yeni bir izlence kurar. İlk kesitin tüm gönderici eyleyenleri (ortak eyleyen) değişir, özne kendi kendisini görevlendiren bağımsız özneye dönüşür. Sistemin şüpheli olarak gözetlediği Dreyman, Dreyman'ın arkadaşları ve aktrist sevgilisi Sieland alıcı olarak konum değiştirir. Dönüşen öznenin anlatı içinde artık yardımcı eyleyeni kalmaz. İlk kesitin gönderici konumunda olan eyleyenleri ise engelleyici haline gelir.

Yeni yitik nesnenin ortaya çıkmasıyla birlikte yeni edinç ve edim evreleri de ortaya çıkar. Özne konumundaki Yüzbaşı, edinç evresinde yıkıcı bilgi olarak tanımlanabilen Dreyman'ın yazmış olduğu eleștirel yazıyı rapor etmez. Sistem tarafından ötekileştirilen, yalnızlaştırılan ve yedi yıl çalışma yasağı konulan tiyatro yönetmeni Albert Jerska'nın intiharı başta olmak üzere Dreyman, Demokratik Alman Cumhuriyeti'nde birçok Doğu Alman sanatçının intiharına yönelik istatistiklere dayanan eleștirel bir makale kaleme alır. Dreyman bu makaleyi Batı Almanya'da yayınlamak ister. Bu makale, sistemin aradığı bilgidir. Yüzbaşı'nın anlatının başındaki yitik nesnesi ve bu nesnenin üzerine kurduğu temel izlencesidir. Fakat Yüzbaşı, bu makaleyi üstlerine bir tiyatro oyunu olarak yansitır ve zararsız bir metin olarak rapor eder. Der Spiegel editörü Gregor Hessenstein'ın kimliğini saklayarak sınır kapısından geçmesine ve Doğu Alman topraklarında dört saat kalmasına göz yumar. Ayrıca Kültür Dairesi Başkanı Albay Grubitz'e, Dreyman'ın şüpheli durumlarını ve eylemlerini içeren raporu sunmaz. Dahası tavan arasında birlikte dinleme yaptıkları Başçavuş Leye'den eleştirel yazı başta olmak üzere bazı bilgileri saklar. Hatta kesitler ilerledikçe Başçavuş'un görevinden alınması gerekliliğini vurgular ve yalnız bir şekilde dinlemeye devam eder. Kültür Bakanı'nın zorla birlikte olmaya yönelik 
davranışlarına Yüzbaşı'nın da yardımıyla cevap vermeyen Christa Maria Sieland Bakan'ın talimatıyla gözaltına alınır. Sorgu sırasında Sieland makalenin Dreyman tarafından yazıldığını ve daktilonun evindeki kapı eşiğinin altında saklandığını itiraf eder. Bunun üzerine Stasi çalışanları Dreyman'ın evine baskın yapar. Özne konumundaki Yüzbaşı, Stasi'den önce Dreyman'ın evine gelir ve intihar vakalarına yönelik eleştirel bilgileri içeren makalenin yazılmış olduğu daktiloyu Dreyman'ın gizlemiş olduğu yerden alır ve saklar. Böylece Dreyman'ı ele verecek olan daktilonun Stasi çalışanları tarafından bulunmasının önüne geçer. Esasında tüm bu eylemler, hem edinç hem de edim evresidir. Özne yitik nesnesine ulaşabilmek adına edinç aşamasında çaba göstererek bilgiye ulaşırken, diğer taraftan da bu çabaları bilgisiyle buluşturur. Edinç aşamasını başarılı bir şekilde gerçekleştirerek bilgi ve güç unsurlarını bünyesinde barındıran kahraman edim evresinde de elde ettiği bu yetileri edimselleştirir. Sonuç olarak özne, anlatının ilerlemesiyle bağımsız özneye dönüșerek kendi kendisini görevlendirdiği yitik nesnesine ulaşır. Böylece anlatının dörtlü şemasındaki ödül ya da ceza (bitiş durumu) evresi, ödül olarak sonuçlanır.

Anlatının sonunda Yüzbaşı Wiesler'ın Dreyman'a yardımları ortaya çıkmaz ama Albay Grubitz tüm olan bitenin farkındadır. Bu nedenle Yüzbaşı'ya kariyerinin bittiğini ve emekliliği gelinceye kadar bir mahzende mektup ayıklayacağını söyler. $\mathrm{Bu}$ durum ceza olarak yorumlansa da anlatının sonunda Dreyman'ın kendisine yapılan yardımı Yüzbaşı'nın raporlarını okuyarak öğrendiği görülür. Dreyman “İyi Bir İnsan İçin Sonat" başlığını taşıyan romanını, kendisini tam gözetim altında tutarak dinleyen fakat şüpheli eylemleri yerine her şeyin normal olduğunu gösteren HGW XX/7 kod adlı özne konumundaki Yüzbaşı Wiesler'a adar. Bu sekans, ödül ceza evresindeki ödülün somutlaşmış halidir. Bu bağlamda özne, yitik nesnesine ulaşır. Böylece anlatının başında nesnesiyle ayrışımsal bir ilişki içinde olan özne (ÖUN), anlatının devamında nesnesine sahip olur ve onunla bağlaşımsal bir ilişki içine girer $(O ̈ \cap N)$. Böylece anlatı arayış nesnesinin bulunmasıyla sona erer.
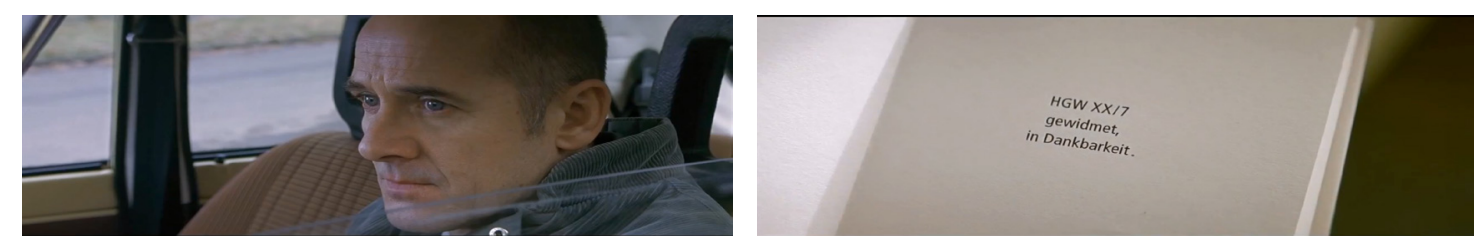

Resim 5-6: Yüzbaşı Wiesler'ın Dreyman'a olan yardımları açığa çıkmaz, ama şüpheli görüldüğünden kariyeri sona erer. Sinematografinin dili de (üst açı-küçümseme) bunu destekler niteliktedir. Fakat Dreyman "İyi Bir İnsan İçin Sonat" başlığını taşıyan romanını, HGW XX/7 kod adlı özne konumundaki Yüzbaşı Wiesler'a adar. Bu sahne, ödül ceza evresindeki ödülün somutlaşmış halidir. Özne işini kaybetse de yitik nesnesine ulaşır.

Dramaturjik bağlamda özne konumundaki Yüzbaşı Wiesler'ın benliği, iktidar ve başkalarının hayatı arasındaki gerilim sonucu ortaya çıkar. Goffman, hayatı bir sahneye benzetir, insanlar da bu sahnede rol yapan birer aktördür. Bu bağlamda anlatının başında Yüzbaşı'nın kamusal senaryo/toplumsal metin temelinde performanslarını gerçekleştirdiği görülür. Uygun eylem kalıplarından/rutinlerden beslenerek iktidarın makbul gördügü birtakım performansları sergiler. Fakat anlatı ilerledikçe kamusal senaryodan vazgeçerek kendisine yeni bir izlence tayin eder. Bu bağlamda öznenin, sahne arkası oluşmaya başlar. Sahne arkasında birtakım taktik ve stratejilerle birlikte yıkıcı bilgiyi saklamanın yollarını arar. Yıkıcı bilgi, daha evvel ifade edildiği gibi izleyicinin ulaşması durumunda performansın zedeleneceği 
hatta ortadan kalkacağı bilgiyi ifade eder. Bu anlatıdaki yıkıcı bilgi, Dreyman'ın şüpheli eylemleri ve yazmıș olduğu eleştirel makaledir. Özne, bu bilgiyi korumakla ve Dreyman'a yardım etmekle kendisini görevlendirir. Bağımsız özneye dönüșen Yüzbaşı, sahne önünde yine uygun eylem kalıplarını seçer ve iktidarın makbul gördüğü performansları sergiler. Raporunda yıkıcı bilgiye yer vermez, aksine her şeyin normal olduğuna yönelik raporlar sunar. Sahne önünde de izlenim denetimine başvurarak performansının zedelenmesine izin vermez. Kahramanın inșa ettiği sahne arkası ve buradaki performansları Dreyman'ın sistem tarafından alıkonulmasına engel olur. Böylece özne, nesnesine ulașır. Yüzbașı'nın sahne arkası ve bu bağlamda sakladığı yıkıcı bilgi aleni bir şekilde ortaya çıkmasa da yine de sistem tarafından statü tahakkümüne uğrayarak daha aşağı bir göreve getirilir. Sahne önünde ve sahne arkasında üretilen performanslar, kamusal senaryo ve sahne arkası eylemlerinin ikili karşıtlığı ve izlenim denetimine yönelik yapılmak zorunda kalınan bir takım davranışlar özne konumundaki kahramanın benliğini oluşturur. Oluşan bu benlik, izleyici tarafından kabul görür ve ideal egoya dönüşen kahramanla özdeşlik kurulur.

\section{Sonuç}

Bu çalışmada kahramanın özne konumu ve benliğinin inşa süreci incelendi. Özne konumundaki kahramanın anlatı içinde değişen yitik nesnesi ve bu bağlamda kurulan izlencesi anlaşılmaya çalışıldı. Anlatının başında yaraları olan ve yaraları dikilmeyen bir kahramanla özdeșlik ilişkisi başlatabilmek son derece güçtür. Bu bağlamda bu yaraların anlatı ilerledikçe dikilmesi geleneksel anlatı sineması bağlamında son derece gereklidir. Başkalarının Hayatı filminin başkahramanı konumundaki Yüzbaşı Wiesler'da anlatının başında ideal bir ego değildir. Bir istihbarat servisi için çalışan, şüphelileri tespit ve rapor eden bir eyleyendir. İzleyicinin özdeşlik ilişkisini başlatabilmesi için değişip dönüşmesi gereklidir. Bu bağlamda öznenin birtakım unsurlarla anlatı boyunca dönüştüğü görülür: Kültür Bakanı'nın Dreyman'ın kız arkadaşı olan aktrist Christa Maria Sieland ile olan ilişkisini Dreyman'a göstermesi, Dreyman'ın Brecht kitabını alıp okuması, Dreyman'ın Beethoven'ın "Appassionata"sını piyanoda çalarken dinlemesi ve "bu müziği gerçekten dinlemiş biri kötü bir insan olabilir mi” diye soran Dreyman'ın sözlerine maruz kalması, yaşamını sürdürebilmek için Kültür Bakanı'yla kendisini görüşmek zorunda hisseden Christa Maria Sieland'ı bu görüşmeden alıkoyması, Dreyman'ın yazmış olduğu eleştirel yazıyı rapor etmemesi, intihar vakalarına yönelik eleştirel bilgileri içeren makalenin yazılmış olduğu daktiloyu Dreyman'ın gizlemiş olduğu yerden alması ve saklaması. Böylece anlatının başında arayan özne konumunda olan yani isteği olan, bilgisi ve gücü olmayan kahramanın sekansların ilerlemesiyle birlikte kendi kendisinin göndericisine dönüștügü görülür. Yani diğer eyleyenlerle girdiği ilișkiler sonucunda özne konumundaki Wiesler, kendisine yeni bir yitik nesne belirler, böylece özerk özne haline gelir. Sonuç olarak anlatının başında arayan özne konumunda olan Wiesler, doğruluk öznesine dönüşür. Yani artık isteğin yerini bilgi ve güç alır. Doğruluk öznesine dönüşen özne, yitik nesnesine de ulaşır. Anlatı içinde izleyici tarafından olumlu olarak değerlendirilen bu değişimleri ve dönüşümleri yaşayan özne konumundaki kahramanla özdeşlik ilişkisi başlatabilmek artık mümkündür.

Bu çalışma kahramanın özne konumunu incelerken aynı zamanda benlik üzerine de odaklandı. Bu anlatıdaki öznenin benliğinin, birtakım ikili karşıtlıklar ve ilişskiler ekseninde oluştuğu görüldü. İlk sekanslarda kamusal senaryodan ya da toplumsal metinlerden beslenen özne, anlatı ilerledikçe bu senaryoları sadece sahne önünde 
sergilemeye başlar. Yani ilk sekanslarda istihbarat servisinin isteklerini uygulayan ve kendisine verilen görevi yerine getirmeye çalışan Wiesler, bir süre sonra yapı karşısında bir faile dönüşür. Kendisine verilen görevleri askıya alır ve yeni bir izlence tayin eder. Sistemin kendisinden beklediği davranışları ve eylemleri taktik ve strateji/gizli senaryo gereği sahne önünde edimselleştirir, bir taraftan da sahne arkasını üretir. Sahne arkası, öznenin korumak durumunda kaldığ yıkıcı bilgi ekseninde oluşur. Yıkıcı bilgi, Dreyman'ın şüpheli eylemleri ve yazmıș olduğu eleștirel makaledir. Wiesler doğruluk öznesine dönüşmeye başlamasıyla birlikte Dreyman'ın şüpheli durumlarını ve eylemlerini rapor etmez. Böylece özne konumundaki Wiesler'ın sahne önündeki tüm performansları ve izlenim denetimi, sahne arkasının ortaya çıkmasını engellemek yani yıkıcı bilgiyi korumak içindir. Anlatı boyunca yaşanan tüm bu gelişmeler ve geçilen aşamalar özne konumundaki kahramanın benliğini inşa eder.

Sonuç olarak Başkalarının Hayatı filmi bağlamında öznenin ulaşmaya çalıştığı yitik nesnesi ve bu bağlamda kurduğu izlencesi, benliğini de şekillendirir. İlerleyen kesitlerde değișen yitik nesne, benliğin de dönüşmesinde rol oynar. Anlatı içindeki kahramanın ideal egoya dönüşmesi, sahne arkasının üretilmesiyle mümkün olur. Anlatı içinde üretilen taktikler, stratejiler ve üretilen birtakım gizli senaryolar benliğin kişinin mülkiyeti olmadığını, toplumun beklediği davranışlarla öznenin spontane bir şekilde gerçekleştirmek istediği davranışlar arasındaki gerilimle şekillendiğini gösterir.

\section{Kaynakça}

Aristoteles, (2011). Poetika: Şiir Sanatı Üstüne (S. Rifat, Çev.). İstanbul: Can Yayınları.

Barthes, R. (2009). Göstergebilimsel Serüven (M. Rifat ve S. Rifat, Çev.). İstanbul: Yapı Kredi Yayınları.

Berberoğlu, B. (2009). Klasik ve Çağdaş Sosyal Teoriye Giriş: Eleştirel Bir Perspektif (C. Cemgil, Çev.). İstanbul Bilgi Üniversitesi Yayınları: İstanbul.

Branigan, E.(1992). Narrative Comprehension and Film. London\&New York: Routledge.

Chatman, S.(2008). Öykü ve Söylem: Filmde ve Kurmacada Anlatı Yapısı (Ö. Yaren, Çev.). Ankara: De Ki Basım Yayım.

Culler, J. (2007). Yazın Kuramı (H. Gür, Çev.). Ankara: Dost Kitabevi Yayınları.

Goffman, E. (2012). Günlük Yaşamda Benliğin Sunumu (B. Cezar, Çev.). İstanbul: Metis Yayınlarl.

Kıran, Z. ve Kıran, A.(2007). Yazınsal Okuma Süreçleri. Ankara: Seçkin Yayıncılık.

Layder, D.(2010). Sosyal Teoriye Giriş (Ü. Tatlıcan, Çev.). İstanbul: Küre Yayınları.

Mutlu, E.(2004). İletişim Sözlügü. Ankara: Bilim ve Sanat Yayınları.

Onega, S. ve Landa G. (2002). Anlatıbilime Giriş (D. Hakyemez ve Y.Salman, Çev.). İstanbul: Adam Yayınları.

Oluk, A.(2008). Klasik Anlatı Sineması. İstanbul: Hayalet Kitap.

Parsa, A. (2012). "Sinema Göstergebiliminde Yapısal Çözümleme: Sinemasal Anlatı Sunumu ve Kodlar", Özlem Güllüoğlu (ed.), İletişim Bilimlerinde Araştırma Yöntemleri: Görsel Metin Çözümleme. Ankara: Ütopya Yayınevi, s. 11-33. 
Poloma, M.(2012). Çağdaş Sosyoloji Kuramları (H. Erbaş, Çev). Ankara: Palme Yayincllı.

Propp, V.(2011). Masalın Biçimbilimi (M. Rifat ve S. Rifat, Çev.). İstanbul: Türkiye İş Bankası Kültür Yayınları.

Rifat, M. (2005). XX. Yüzyılda Dilbilim ve Göstergebilim Kuramları 1. Tarihçe ve Eleștirel Düşünceler. İstanbul: YKY.

Rifat, M. (1999). Gösterge Eleştirisi. İstanbul: Kaf Yayıncılık.

Rifat, M. (1990). Dilbilim ve Göstergebilimin Çağdaş Kuramları. İstanbul: Düzlem Yayınları.

Ritzer, G. (2013a). Sosyoloji Kuramları, (H. Hülür, Çev.). Ankara: De Ki Basım Yayım.

Ritzer, G. (2013b). Modern Sosyoloji Kuramları (H. Hülür, Çev.). Ankara: De Ki Basım Yayım. 
